\title{
DUKUNGAN SOSIAL KELUARGA TERHADAP LANSIA
}

\author{
Nurrohmi \\ Politeknik Kesejahteraan Sosial Bandung, Jln. Ir. H. Juanda Nomor 367, Dago, \\ Bandung,40135 nurrohmi1960@gmail.com
}

\begin{abstract}
The research purpose is to describe the family social support toward the elderly involving four aspects, namely instrumental, informational, emotional, and appreciation supports. This research used descriptive method with qualitative approach. Data collection consisted of in-depth interviews, observations, and document study. The data analysis was undertaken by reducing data, displaying data, and by means of verification. The data validity used namely triangulation, intent observation, and references usage. The research results showed that the family had provided social support for the elderly which consisted of: (1) Instrumental support given to the elderly was in the forms of money provided every day, every two weeks and every three months, food provided every day, and clothes for taking a pray when Idul Fitri, which all were carried out well. (2) Informational support consisted of advice and suggestion, provided for the elderly when the elderly had to take a medicine, go to the hospital to check her health, and also when the elderly washed her clothes by herself and the family prohibited her to do it. These were carried out by the family well. (3) Emotional support comprised attention and care, done when the elderly felt sad, cried, was alone, and sick, this emotional support was provided by the family well. (4) Appreciation support was in the form of agreements for the elderly's opinion, in this case, the family always agreed what the elderly said, and desire of elderly implemented when the elderly wanted to follow Islamic activity such as "Pengajian", this appreciation support was implemented by the family well. Based on the research results it might be concluded that the family had given social support to the elderly well in order that the needs of the elderly could be met, both physical needs, and psychosocial needs.
\end{abstract}

Keywords:

Social support; Family; Elderly

\begin{abstract}
Abstrak
Tujuan penelitian ini untuk mengetahui bentuk dukungan sosial yang diberikan keluarga kepada lanjut usia yang tinggal serumah. Terdapat empat bentuk dukungan sosial yang diberikan keluarga kepada lanjut usia yang merupakan aspek yang diteliti yaitu dukungan instrumental, dukungan informasional, dukungan emosional, dan dukungan penghargaan. Penelitian ini menggunakan metode penelitian deskriptif dengan pendekatan kualitatif. Sumber data dalam penelitian ini yaitu sumber data primer. Teknik pengumpulan data yang digunakan adalah wawancara mendalam, observasi dan studi dokumentasi. Analisis data dilakukan melalui reduksi data, penyajian data, dan penarikan kesimpulan. Keabsahan data menggunakan triangulasi, ketekunan pengamatan, dan penggunaan bahan referensi. Hasil penelitian menunjukkan bahwa dukungan sosial yang diberikan keluarga kepada lanjut usia mencakup : (1) Dukungan emosional yang diberikan dalam bentuk perhatian dan kepedulian yang dilakukan apabila lanjut usia sedang sakit, sedang sedih, sedang menyendiri dan melamun, dukungan emosional diberikan oleh keluarga dengan cara yang baik. (2) Dukungan penghargaan diberikan oleh keluarga kepada lanjut
\end{abstract}


usia berupa persetujuan akan pendapat dan keinginan lanjut usia yang dilakukan ketika lanjut usia ingin mengikuti pengajian, dukungan penghargaan diberikan dengan cara yang baik. (3) Dukungan instrumental yang diberikan yaitu berupa uang, diberikan setiap hari, setiap dua minggu sekali, tiga bulan sekali; makanan diberikan setiap hari, pakaian, mukena, diberikan oleh keluarga pada saat lebaran, dukungan diberikan dengan cara yang baik. (4) Dukungan informasional diberikan keluarga kepada lanjut usia dalam bentuk saran dan nasihat yang dilakukan pada saat lanjut usia harus minum obat, harus pergi ke rumah sakit untuk kontrol, pada saat lanjut usia mencuci pakaian sendiri, keluarga melarangnya, dukungan informasional dilakukan oleh keluarga dengan cara yang baik. Dukungan sosial kepada lanjut usia sudah diberikan oleh keluarga dengan baik sehingga lanjut usia dapat memenuhi kebutuhannya baik secara fisik, maupun psikososialnya.

\section{Kata Kunci:}

Dukungan social; Keluarga; Lanjut Usia 


\section{PENDAHULUAN}

Lanjut usia atau yang lebih sering disebut lansia dapat dikatakan sebagai fase kehidupan akhir yang akan dilalui oleh manusia yang diberikan umur panjang, karena tidak semua orang berumur panjang. Berdasarkan UndangUndang Nomor 13 Tahun 1998 dalam Bab I Pasal 1 Ayat 2 dikatakan bahwa lanjut usia adalah seseorang yang mencapai usia enam puluh tahun keatas, yang dimana pada umur tersebut lanjut usia akan mengalami penurunan baik fungsi fisik maupun psikis. Namun dengan adanya kemajuan pengetahuan dan teknologi terutama dalam bidang ilmu kesehatan, penanganan penyakit dan pelayanan kesehatan bagi lanjut usia semakin baik. Hal ini berdampak terhadap kenaikan angka harapan hidup.

Berdasarkan sensus penduduk yang dilakukan, angka harapan hidup di Indonesia akan mencapai 71 tahun. Angka tersebut tentu saja diiringi dengan kenaikan jumlah penduduk lanjut usia seperti terlihat pada Tabel 1.1 berikut ini.

Tabel 1.1 Usia Harapan Hidup dan Jumlah Lanjut usia

\begin{tabular}{|c|c|c|c|}
\hline Tahun & $\begin{array}{c}\text { Usia } \\
\text { Harapan } \\
\text { Hidup }\end{array}$ & $\begin{array}{c}\text { Jumlah } \\
\text { Lanjut Usia }\end{array}$ & Proporsi \\
\hline 1980 & 52,2 & 7.998 .543 & $5,45 \%$ \\
\hline 1990 & 59,8 & 11.277 .557 & $6,29 \%$ \\
\hline 2000 & 64,5 & 14.439 .967 & $7,18 \%$ \\
\hline 2010 & 67,4 & 23.992 .553 & $9,77 \%$ \\
\hline 2020 & 71,1 & 28.822 .879 & $11,34 \%$ \\
\hline
\end{tabular}

Sumber: BPS, 2014 (Badan Pusat Statistik)

Jumlah penduduk lanjut usia yang besar tersebut akan memberikan peluang sekaligus tantangan. Jumlah penduduk yang besar apabila dikelola dengan baik akan menjadi modal dasar dan aset yang berharga dalam proses pembangunan. Namun apabila pertambahan jumlah penduduk lanjut usia tidak diimbangi dengan kualitasnya maka akan menjadi masalah dan beban dalam pembangunan.

Bertambahnya jumlah lanjut usia menimbulkan dampak terhadap berbagai aspek kehidupan, baik bagi lanjut usia sendiri, keluarga, masyarakat maupun pemerintah. Semakin meningkat angka harapan hidup maka beban ketergantungan usia non produktif terhadap usia produktif akan semakin meningkat pula. Hal ini dikarenakan pada masa lanjut usia individu akan mengalami beberapa perubahan terkait dengan menurunnya beberapa fungsi di antaranya penurunan fungsi fisik, kognitif, penurunan fungsi dan potensi seksual serta perubahan aspek psikososial. Penurunan fungsi ini membuat lanjut usia harus mengalami ketergantungan kepada orang lain dan harus memperoleh prioritas utama dalam penanganannya agar lanjut usia tetap dapat menjalankan fungsi serta kebutuhannya, baik kebutuhan fisik, maupun psikososialnya, karena manusia sebagai makhluk sosial tidak dapat hidup sendiri melainkan akan selalu membutuhkan bantuan orang lain. Kebutuhan fisik seseorang (sandang, pangan, papan), kebutuhan sosial (pergaulan, pengakuan, sekolah, pekerjaan) dan kebutuhan psikis termasuk rasa ingin tahu, rasa aman, perasaan religiusitas, tidak mungkin terpenuhi tanpa bantuan orang lain. Apalagi orang tersebut sedang menghadapi masalah, baik ringan maupun berat. Pada saat seperti itu seseorang akan mencari dukungan sosial dari orang di sekitarnya, sehingga dirinya merasa dihargai, diperhatikan dan dicintai (Lilik Ma'rifatul Azizah, 2011). Dalam memenuhi kebutuhannya, sebagian lanjut usia terutama yang sudah tidak potensial memerlukan 
bantuan dari orang lain bahkan bergantung kepada orang lain. Hal ini mengacu pada Undang-Undang No. 13 Tahun 1998 Pasal 1 Ayat 4, bahwa lanjut usia tidak potensial adalah lanjut usia yang tidak berdaya mencari nafkah sehingga hidupnya bergantung pada bantuan orang lain. Dalam hal ini, diharapkan keluarga dapat mengambil posisi penting dalam kehidupan lanjut usia. Dalam Undang-Undang No. 13 Tahun 1998 Pasal 1 Ayat 6 mengenai Kesejahteraan Lanjut Usia dikatakan bahwa keluarga adalah unit terkecil dalam masyarakat yang terdiri dari suami-istri, atau suami istri dan anaknya, atau ayah dan anaknya, atau ibu dan anaknya beserta kakek dan/atau nenek. Pernyataan Pasal 1 Ayat 6 tersebut menyiratkan bahwa keluarga merupakan orang terdekat yang mempunyai posisi penting dalam hidup lanjut usia. Tanpa lanjut usia atau orangtua maka tidak akan ada anak beserta generasi mendatang yang tumbuh. Terkait dengan tanggung jawab keluarga terhadap orang tua, dalam hal ini lanjut usia, sudah tercantum dalam Pasal 8 Undang-Undang No.13 Tahun 1998 bahwa pemerintah, masyarakat, dan keluarga bertanggung jawab atas terwujudnya upaya peningkatan kesejahteraan sosial lanjut usia.

Indonesia sebagai negara yang menganut budaya Ketimuran masih menjunjung prinsip bahwa merawat orangtua merupakan sebuah kewajiban anak sebagai tanda bakti. Prinsip ini juga dituangkan dalam NKKBS yaitu Norma Kecil Keluarga Bahagia Sejahtera. Dengan merawat orangtua, seorang anak dapat melakukan penghormatan kepada orangtua tanpa proteksi yang berlebihan. Dengan merawat orangtua seorang anak dapat mencurahkan kasih sayangnya kepada orangtua atau lanjut usia.
Hasil Proyeksi Penduduk Indonesia tahun 2010-2035, jumlah penduduk lansia di Jawa Barat pada tahun 2017 sebanyak 4,16 juta jiwa atau sekitar 8,67 persen dari total penduduk Jawa Barat (https:// jabar. bps.go.id). Penduduk lansia di Jawa Barat, berdasarkan data statistik meningkat setiap tahunnya, dan di tahun 2018 sudah di angka 11 persen (https://jabarprov.go.id). Untuk mewujudkan penghargaan kepada lanjut usia, Provinsi Jawa Barat telah merumuskan program operasional dari Undang-Undang No. 13 Tahun 1998 yang berbasis kearifan lokal yaitu silih asih, silih asah, dan silih asuh dengan nama program "Nyaah ka Kolot". Nyaah ka Kolot merupakan bagian dari kearifan lokal yang bermakna rasa kasih sayang yang mendalam, dan penuh ketulusan seorang anak kepada orangtua. Pemberian penghormatan dan kasih sayang merupakan bagian dari dukungan sosial.

Dukungan sosial didefinisikan sebagai informasi verbal atau nonverbal, saran, bantuan yang nyata atau tingkah laku yang diberikan oleh orang yang akrab dengan subjek di dalam lingkungan sosialnya atau yang berupa kehadiran dan hal-hal yang dapat memberikan keuntungan emosional atau berpengaruh pada tingkah laku penerimanya (Lilik Ma'rifatul Azizah, 2011). Menurut Ritter, dukungan sosial merupakan segi-segi struktural jaringan mencakup pengaturan-pengaturan hidup, frekuensi kontak, keikutsertaan dalam kegiatan sosial, keterlibatan dalam jaringan sosial. Dukungan sosial mengacu pada bantuan emosional, instrumental, dan finansial yang diperoleh dari jaringan sosial seseorang. Segisegi fungsional mencakup dukungan emosional, mendorong adanya ungkapan perasaan, pemberian nasihat atau informasi, pemberian bantuan material (Smet, 1994, dikutip Muchlisin, 2017). 
Dukungan sosial adalah tindakan yang bersifat membantu yang melibatkan emosi, pemberian informasi, bantuan instrumen, dan penilaian positif pada individu dalam menghadapi permasalahannya (Apollo dan Cahyadi, 2012, dikutip Muchlisin, 2017).

Lanjut usia yang hidup bersama dengan keluarganya, seperti anak, istri, suami, dan kerabat diharapkan akan mendapatkan dukungan sosial dari keluarga sebagai sumber dukungan sosial. Sumber dukungan sosial dapat berupa dukungan sosial natural, yaitu yang natural diterima seseorang melalui interaksi sosial dalam kehidupannya secara spontan dengan orang-orang yang berada di sekitarnya, misalnya anggota keluarga (anak, istri, suami dan kerabat), teman dekat atau relasi, dan dukungan sosial ini sifatnya nonformal (Kuntjoro, 2012, dikutip Muchlisin 2017). Pengertian-pengertian tersebut menyiratkan bahwa dukungan sosial dapat berbentuk material maupun non material yang diberikan dengan melibatkan emosi dan penilaian yang positif untuk meringankan permasalahan yang dialami oleh seseorang.

Lanjut usia, apalagi yang tinggal serumah dengan anak kandung ataupun anak menantu, apalagi lanjut usia yang sudah tidak potensial yang bergantung pada bantuan orang lain sudah tentu akan sangat memerlukan dukungan sosial dari keluarganya seperti dari anak kandung dan/atau anak menantu. Dukungan sosial (Lilik Ma'rifatul Azizah, 2011; Sarafino dalam Muchlisin, 2017) dapat dilihat dari beberapa aspek, sebagai berikut:

\section{Dukungan Instrumental}

Bentuk dukungan ini merupakan penyediaan materi yang dapat memberikan pertolongan langsung seperti pinjaman uang, pemberian barang, makanan serta pelayanan. Bentuk dukungan ini dapat mengurangi stres karena individu dapat langsung memecahkan masalahnya yang berhubungan dengan materi. Dukungan instrumental sangat dibutuhkan terutama dalam mengatasi masalah dengan lebih mudah.

\section{Dukungan Informasional}

Bentuk dukungan ini melibatkan pemberian informasi, saran atau umpan balik tentang situasi dan kondisi individu. Jenis informasi seperti ini dapat menolong individu untuk mengenali dan mengatasi masalah dengan lebih mudah.

\section{Dukungan Emosional}

Bentuk dukungan emosional dapat membuat individu memiliki perasaan nyaman, yakin, diperdulikan dan dicintai oleh sumber dukungan sosial sehingga individu dapat menghadapi masalah dengan lebih baik. Dukungan ini sangat penting dalam menghadapi keadaan yang dianggap tidak dapat dikontrol.

\section{Dukungan Penghargaan}

Bentuk dukungan ini berupa penghargaan positif kepada individu, pemberian semangat, persetujuan pada pendapat individu, perbandingan yang positif dengan individu lain. Bentuk dukungan ini membantu individu dalam membangun harga diri dan kompetensi.

Dukungan sosial merupakan bantuan atau dukungan yang diterima individu dari orangorang tertentu dalam kehidupannya. Diharapkan dengan adanya dukungan sosial maka seseorang akan merasa diperhatikan, dihargai dan dicintai. Dukungan sosial dapat memberikan kenyamanan fisik dan psikologis kepada individu dapat dilihat bagaimana dukungan sosial mempengaruhi kejadian dan efek dari keadaan kecemasan. Lanjut usia sebagai seseorang yang berada dalam lingkungan keluarga diharapkan akan 
merasakan manfaat dukungan sosial yang diberikan oleh keluarga karena dukungan sosial dapat mempengaruhi fisik dan psikologis individu yang diijelaskan dalam dua teori berikut:

\section{The Buffering Hyphotesis}

Menurut teori ini, dukungan sosial melindungi individu dengan melawan efekefek negatif dari tingkat stres yang tinggi, yaitu dengan dua cara berikut:

a. Ketika individu menghadapi stressor yang kuat, seperti krisis keuangan maka individu dengan tingkat dukungan sosial yang tinggi menjadi kurang melihat situasi tersebut sebagai situasi yang penuh stres, bila dibandingkan dengan individu dengan tingkat dukungan sosial yang rendah. Individu dengan tingkat dukungan sosial yang tinggi berharap bahwa seseorang yang dikenal individu akan menolong individu tersebut.

b. Dukungan sosial dapat mengubah respon seseorang terhadap stressor yang telah diterima sebelumnya. Contohnya, individu dengan dukungan sosial yang tinggi mungkin memiliki seseorang yang dapat memberikan solusi terhadap masalah individu, atau melihat masalah tersebut sebagai suatu yang tidak terlalu penting, atau membuat individu dapat menemukan titik terang dari masalah tersebut.

\section{The Direct Effect Hyphotesis}

Individu dengan tingkat dukungan sosial yang tinggi memiliki perasaan yang kuat bahwa individu tersebut dicintai dan dihargai. Individu dengan dukungan sosial tinggi merasa bahwa orang lain peduli dan membutuhkan individu tersebut, sehingga hal ini dapat mengarahkan individu pada gaya hidup yang sehat. (Sarafino, 2006, dikutip Muchlisin, 2017)

Meskipun dalam kenyataannya tidak semua keluarga dapat memberikan dukungan sosial kepada lanjut usia karena berbagai hal, terutama faktor ekonomi, tetapi keluarga di Kelurahan Sindang Kasih Kabupaten Purwakarta masih memegang nilai bahwa orangtua harus diurus, harus dihargai, dihormati. Lanjut usia yang tinggal dalam satu rumah dengan keluarga, mendapatkan dukungan sosial dari keluarganya dalam hal ini dari anak kandung dan dari menantu.

Data dari Dinas Sosial Kabupaten Purwakarta menunjukkan bahwa jumlah penduduk lansia sebanyak 2304 (tahun 2019) dan jumlah lansia di Kelurahan Sindangkasih sebanyak 30 orang yang merupakan jumlah penerima bantuan PKH terbanyak. Hal ini menyiratkan bahwa lansia di Kelurahan Sindangkasih banyak yang tinggal bersama keluarga. Oleh sebab itu, penelitian ini dilakukan untuk mengetahui lebih jauh dan mendalam bagaimana dukungan sosial yang diberikan oleh keluarga di Kelurahan Sindangkasih Kabupaten Purwakarta.

\section{METODE}

Metode yang digunakan dalam penelitian ini yaitu metode deskriptif dengan pendekatan kualitatif, yaitu agar diperoleh data yang spesifik, lengkap, dan mendalam tentang subyek dan obyek penelitian dari berbagai perspektif yang terkait, sehingga dapat dipaparkan gambaran situasi dan kondisi di lapangan sebagai bahan analisis untuk diambil kesimpulan.

Sumber data dalam penelitian ini terdiri dari sumber data primer dan sumber data sekunder. Teknik pengumpulan data dilakukan melalui wawancara mendalam, observasi non 
partisipatif dan studi kepustakaan terhadap berbagai literatur terkait konteks penelitian.

Analisis data dilakukan melalui reduksi data, penyajian data, dan penarikan kesimpulan. Pemeriksaan keabsahan data yang digunakan dalam penelitian ini yaitu triangulasi, ketekunan pengamatan, dan penggunaan bahan referensi. Adapun pemilihan informan sesuai dengan pernyataan Moleong bahwa informan adalah orang-orang yang berada pada latar penelitian yang dimanfaatkan untuk memberikan informasi tentang situasi dan kondisi latar penelitian (Moleong, 2000 dikutip oleh Tukino, Meilani Dewi, dkk, 2016). Informan yang dipilih dianggap mengetahui dan mempunyai kapasitas sesuai dengan keperluan penelitian ini. Teknik penentuan informan dilakukan secara purposive, yaitu informan keluarga, dalam hal ini anak kandung dan anak menantu sebanyak 2 (dua) orang dan lanjut usia sebagai orangtua sebanyak 2 (dua) orang.

\section{HASIL PENELITIAN}

Penelitian ini meneliti tentang dukungan sosial keluarga terhadap lanjut usia yang mencakup aspek dukungan instrumental, dukungan informasional, dukungan emosional, dan dukungan penghargaan.

\section{Dukungan Instrumental}

Semua informan keluarga (Di dan DR) sudah memberikan dukungan instrumental kepada lansia, meskipun bentuknya tidak semua sama. Informan Di memberikan dukungan instrumental berupa uang, makanan, pakaian, dan mukena. Sedangkan Informan DR memberi uang dan makan kepada lansia.

Informan Di memberi lansia uang setiap hari untuk jajan sebagai hasil mengojek, dan tiga bulan sekali, karena lansia mendapat bantuan PKH yang diberikan tiga bulan sekali. Sedangkan Informan DR memberi lansia uang dua minggu sekali, karena suami Informan DR mengirimi uang setiap dua minggu sekali, dan memberi atau menyiapkan makan untuk lansia setiap hari. Selain memberi uang, Informan Di juga memberi lansia pakaian dan mukena pada saat Lebaran. Sedangkan Informan DR tidak memberikan lansia pakaian atau mukena, karena Informan DR pun tergantung pada pemberian uang dari suaminya.

Semua informan keluarga (Di dan DR) memberikan dukungan instrumental dengan cara yang baik. Pemberian dukungan instrumental keluarga terhadap lansia sudah diterima oleh lansia (Informan Nu dan Ma). Informan $\mathrm{Nu}$ membenarkan bahwa Informan Di sebagai anak kandung lansia memberikannya uang untuk jajan setiap hari setelah pulang mengojek, dan tiga bulan sekali uang dari bantuan PKH. Selain menerima uang, lansia pun membenarkan bahwa keluarga memberikan makan setiap hari dan makanan lain. Informan $\mathrm{Nu}$ juga menerima pemberian pakaian dan mukena pada saat lebaran.

Lanjut usia (Informan Ma) membenarkan bahwa Informan DR sebagai menantunya sudah memberikan dukungan instrumental berupa pemberian makan setiap hari dan uang dua minggu sekali.

Semua lansia (Informan $\mathrm{Nu}$ dan $\mathrm{Ma}$ ) mengatakan bahwa keluarga sudah memberikan dukungan instrumental dengan baik.

\section{Dukungan Informasional}

Semua informan keluarga (Di dan DR) sudah memberikan dukungan informasional kepada lansia, dengan bentuk yang sama. Informan Di memberikan dukungan 
informasional dalam bentuk saran yang cenderung ke arah mengingatkan, begitu pula Informan DR.

Informan Di memberikan saran atau mengingatkan kepada lansia untuk tidak mencuci pakaian sendiri karena masih ada yang muda-muda seperti menantu dan cucucucu lansia. Begitu pula Informan Di menyarankan lansia untuk tidak makan makanan yang mengundang penyakit asma nya kambuh. Selain itu, Informan Di juga mengingatkan lansia untuk kontrol kesehatannya ke Puskesmas.

Informan DR selalu memberikan saran atau mengingatkan lansia untuk minum obat karena khawatir penyakit kolesterol dan darah tinggi lansia kambuh. Selain itu, Informan DR pun mengingatkan lansia untuk kontrol kesehatannya ke rumah sakit. Semua informan keluarga (Di dan DR) memberikan dukungan informasional dengan cara yang baik.

Pemberian dukungan informasional keluarga terhadap lansia sudah diterima oleh lansia (Informan $\mathrm{Nu}$ dan $\mathrm{Ma}$ ). Informan $\mathrm{Nu}$ membenarkan bahwa Informan Di sebagai anak kandung lansia mengingatkannya untuk tidak mencuci pakaiannya sendiri dan mengingatkan untuk tidak makan makanan yang mengundang penyakit asmanya kambuh.

Lanjut usia (Informan Ma) pun membenarkan sudah menerima dukungan informasional dari keluarga berupa saran agar dirinya tidak lupa untuk minum obat sehingga penyakit kolesterol dan darah tingginya tidak kambuh.

Semua lansia (Informan $\mathrm{Nu}$ dan $\mathrm{Ma}$ ) mengatakan bahwa keluarga sudah memberikan dukungan informasional dengan baik.

\section{Dukungan Emosional}

Semua informan keluarga (Di dan DR) sudah memberikan dukungan emosional kepada lansia, dengan bentuk yang sama. Informan Di memberikan dukungan emosional berupa menyenangkan hati lansia dan menghibur, begitu juga Informan DR. Apabila mempunyai rizki, Informan Di selalu menyenangkan hati lansia dengan membelikan buah-buahan apalagi saat lansia sakit. Selain itu, apabila lansia sedang sedih, melamun seorang diri dan menangis, Informan Di menghibur dengan mengatakan bahwa lansia jangan banyak pikiran. Informan DR menganggap lansia seperti ibu kandungnya sendiri. Informan DR selalu menyenangkan hati lansia dengan cara bersabar atas apapun dan bagaimanapun yang penting lansia senang hatinya dan sehat. Selain itu, Informan DR mau mendengarkan saat lansia "curhat" dan menghiburnya dengan meminta lansia tidak banyak yang difikirkan.

Semua informan keluarga (Di dan DR) memberikan dukungan emosional kepada lansia dengan cara yang baik. Pemberian dukungan emosional keluarga terhadap lansia sudah diterima oleh lansia (Informan $\mathrm{Nu}$ dan $\mathrm{Ma}$ ).

Informan $\mathrm{Nu}$ membenarkan bahwa Informan Di sebagai anak kandung lansia menyenangkan hatinya dengan membelikan buah-buahan untuknya apalagi kalau sedang sakit. Informan $\mathrm{Nu}$ juga membenarkan bahwa Informan Di sebagai putra kandungnya selalu menghiburnya apabila dia sedang sedih, sedang menangis dan sedang melamun dengan meminta lansia jangan banyak pikiran.

Lanjut usia (Informan Ma) pun membenarkan sudah menerima dukungan 
emosional dari keluarga yaitu dari menantunya (Informan DR) dengan mau mendengarkan "curhatnya" dan selalu sabar menghadapi dirinya yang penting dirinya senang dan sehat. Semua informan lansia (Informan $\mathrm{Nu}$ dan $\mathrm{Ma}$ ) mengatakan bahwa keluarga sudah memberikan dukungan emosional dengan baik.

\section{Dukungan Penghargaan}

Semua informan keluarga (Di dan DR) sudah memberikan dukungan penghargaan kepada lansia, dengan bentuk yang berbeda. Informan Di memberikan dukungan penghargaan berupa pemberian persetujuan kepada lansia dan permintaan doa dari lansia. Informan Di memberikan dukungan penghargaan kepada lansia dengan menyetujui lansia untuk pergi dan mengikuti pengajian agar lansia juga tidak merasa bosan dan suntuk tinggal di rumah.

Selain itu, Informan Di sebelum berangkat mengojek selalu meminta didoakan kepada lansia agar mengojeknya lancar dan dapat rizki. Informan Di juga minta doa dari lansia apabila ada masalah.

Informan DR memberikan dukungan penghargaan berupa kesediaan melakukan apapun untuk lansia asalkan lansia sehat. Dalam hal ini Informan DR mau tinggal bersama lansia dan mengurus serta merawat lansia.

Selain itu, Informan DR tidak pernah membanding-bandingkan lansia dengan orangtua lainnya. Dalam hal ini, Informan DR sangat menghargai lansia sebagaimana menghormati orangtua kandungnya sendiri. Semua informan keluarga (Di dan DR) memberikan dukungan penghargaan kepada lansia dengan cara yang baik. Pemberian dukungan penghargaan keluarga terhadap lansia sudah diterima oleh lansia (Informan $\mathrm{Nu}$ dan $\mathrm{Ma}$ ).

Informan $\mathrm{Nu}$ membenarkan bahwa Informan Di sebagai anak kandung lansia menyetujui keinginannya untuk mengikuti pengajian sehingga dirinya tidak merasa bosan dan suntuk tinggal di rumah. Selain itu, Informan $\mathrm{Nu}$ juga membenarkan bahwa Informan Di selalu minta didoakan kepadanya sebelum berangkat mengojek agar dapat rizki dan juga selalu minta didoakan apabila ada masalah.

Lanjut usia (Informan Ma) juga membenarkan sudah menerima dukungan penghargaan dari keluarga yaitu dari menantunya (Informan DR) dengan mau melakukan apa saja agar dirinya selalu sehat, dengan mau mengurus dan merawatnya seperti kepada orangtua kandung sendiri. Semua informan lansia (Informan $\mathrm{Nu}$ dan Ma) mengatakan bahwa keluarga sudah memberikan dukungan penghargaan dengan cara yang baik.

\section{PEMBAHASAN}

\section{Dukungan Instrumental}

Lilik (2011) menyatakan bahwa dukungan instrumental yaitu penyediaan materi yang dapat memberikan pertolongan langsung seperti pinjaman uang, pemberian barang, makanan serta pelayanan. Bentuk dukungan ini dapat mengurangi stres karena individu dapat langsung memecahkan masalah yang berhubungan dengan materi. Dukungan instrumental sangat dibutuhkan dalam mengatasi masalah dengan lebih mudah.

Hasil penelitian menunjukkan bahwa keluarga memberikan dukungan instrumental berupa pemberian uang, makanan, pakaian, bahkan mukena. Keluarga merasa berkewajiban memberikan 
dukungan instrumental berupa uang karena lansia sebagai manusia pada umumnya memerlukan uang untuk jajan atau keperluan lainnya. Selain pemberian uang, keluarga juga memberi lansia makan dan makanan juga pakaian dan mukena. Keluarga juga merasa berkewajiban memberikan dukungan sandang dan pangan kepada lansia karena tidak ada lagi orang yang dapat memberikannya selain keluarga karena keluarga sebagai sumber dukungan sosial terdekat bagi lansia. (Lilik Ma'rifatul Azizah, 2011).

Pemberian dukungan dalam bentuk ini dapat mengatasi masalah lansia yang berhubungan dengan pemenuhan kebutuhan fisik, seperti sandang dan pangan. Dengan adanya pemberian dukungan instrumental oleh keluarga maka kebutuhan fisik lanjut usia, seperti kebutuhan akan sandang dan pangan dapat terpenuhi.

\section{Dukungan Informasional}

Menurut Lilik (2011), bahwa dukungan ini melibatkan pemberian informasi, saran atau umpan balik tentang situasi dan kondisi individu. Jenis informasi seperti ini dapat menolong individu untuk mengenali dan mengatasi masalah dengan lebih mudah.

Hasil penelitian menunjukkan bahwa keluarga memberikan dukungan informasional berupa saran atau mengingatkan. Keluarga merasa berkewajiban memberikan informasi berupa saran atau mengingatkan lansia untuk tidak melakukan hal-hal yang dapat menimbulkan masalah bagi lansia dalam hal ini keluarga mengingatkan lansia untuk tidak mencuci pakaian sendiri dan tidak makan makanan yang mengundang penyakit asma yang lansia derita. Pemberian dukungan ini dapat memberikan informasi kepada lansia sehingga lansia mengenali dan dapat mengatasi masalahnya yang berhubungan dengan kesehatan. Pemberian dukungan informasional oleh keluarga dapat menjaga kesehatan lansia dengan melakukan kontrol kesehatan secara rutin ke Puskesmas dan ke Rumah sakit yang difasilitasi oleh keluarga. Oleh karena itu, dengan adanya pemberian dukungan informasional oleh keluarga maka kebutuhan fisik lanjut usia, seperti kebutuhan akan kesehatan dapat terpenuhi.

\section{Dukungan Emosional}

Menurut Lilik (2011), bentuk dukungan emosional dapat membuat individu memiliki perasaan nyaman, yakin, diperdulikan dan dicintai oleh sumber dukungan sosial sehingga individu dapat menghadapi masalah dengan lebih baik. Dukungan ini sangat penting dalam menghadapi keadaan yang dianggap tidak dapat dikontrol.

Hasil penelitian menunjukkan bahwa lanjut usia memperoleh dukungan emosional dari keluarga yaitu keluarga menyenangkan hati lansia dan menghibur lansia. Keluarga memperhatikan lansia ketika lansia tampak sedih dan menangis dan melamun, keluarga melakukan komunikasi dengan mengatakan bahwa lansia tidak perlu banyak fikiran. Hal ini dilakukan karena keluarga merupakan kelompok sosial utama yang mempunyai ikatan emosi yang paling besar dan terdekat dengan lanjut usia, misalnya dengan cara saling berkomunikasi (Lilik Ma'rifatul Azizah, 2011). Dengan pemberian dukungan emosional, lansia merasa senang hatinya dan merasa terhibur maka lansia dapat mengatasi masalah yang berhubungan dengan psikologis. Dengan diberikannya dukungan emosional oleh keluarga maka 
kebutuhan psikologis lansia dapat terpenuhi, yaitu merasa diperhatikan dan dicintai.

\section{Dukungan Penghargaan}

Menurut Lilik (2011), bentuk dukungan ini berupa penghargaan positif kepada individu, pemberian semangat, persetujuan pada pendapat individu, perbandingan yang positif dengan individu lain. Bentuk dukungan ini membantu individu dalam membangun harga diri dan kompetensi.

Hasil penelitian menunjukkan bahwa keluarga memberikan dukungan penghargaan kepada lansia berupa pemberian persetujuan akan keinginan dan pendapat lansia. Keluarga memberikan persetujuan akan keinginan dan pendapat lansia dan juga tidak membandingkan lansia dengan orangtua lainnya. Pemberian persetujuan kepada lansia untuk mengikuti Pengajian, membuat lansia dapat mengatasi masalahnya yaitu rasa bosan dan suntuk untuk diam di rumah terus menerus. Dengan adanya keluarga memberikan dukungan penghargaan maka lansia merasa memiliki harga diri dan kompetensi. Dengan memberikan persetujuan atas apa yang dikatakan lansia dan dengan tidak membandingkan dengan orang lain dengan hal yang negatif maka lansia merasa dihargai sehingga dapat membangun harga dirinya dan dapat memberikan semangat hidup bagi lansia. Dengan adanya pemberian dukungan penghargaan dari keluarga maka lansia dapat menyelesaikan masalahnya yang berhubungan dengan psikologis dan sosialnya. Oleh karena itu, pemberian dukungan penghargaan oleh keluarga dapat memenuhi kebutuhan psikologis dan sosial lansia.

\section{KESIMPULAN}

Penelitian ini mengenai dukungan sosial keluarga terhadap lanjut usia yang terdiri dari dukungan instrumental, dukungan informasional, dukungan emosional, dan dukungan penghargaan.

\section{Dukungan Instrumental}

Dukungan ini sudah diberikan oleh keluarga dalam hal ini keluarga memberikan dukungan dalam bentuk uang, makanan dan pakaian. Dukungan ini dapat bermanfaat bagi lansia untuk mengatasi masalahnya dan dapat memenuhi kebutuhannya yang berhubungan dengan kebutuhan fisiknya yaitu berupa sandang dan pangan.

\section{Dukungan Informasional}

Dukungan ini sudah diberikan oleh keluarga dalam hal ini keluarga memberikan saran atau mengingatkan kepada lansia bahwa lansia harus menjaga kesehatannya dengan tidak melakukan mencuci pakaiannya sendiri dan tidak makan makanan yang mengundang penyakitnya kambuh. Dukungan ini dapat bermanfaat bagi lansia untuk mengatasi masalahnya dan dapat memenuhi kebutuhannya yang berhubungan dengan kebutuhan fisik, yaitu kesehatannya.

\section{Dukungan Emosional}

Dukungan ini sudah diberikan oleh keluarga dalam hal ini keluarga memberi kenyamanan kepada lansia dengan menyenangkan hatinya dengan membelikan buah-buahan dan juga memberikan perhatian dan menghibur lansia saat lansia merasa sedih, menangis, dan melamun seorang diri. Dukungan ini dapat bermanfaat bagi lansia untuk mengatasi masalahnya dan memenuhi kebutuhan yang berhubungan dengan kebutuhan psikologisnya, yaitu perasaan diperhatikan dan dicintai. 


\section{Dukungan Penghargaan}

Dukungan ini sudah diberikan oleh keluarga dalam hal ini keluarga memberikan persetujuan kepada lansia yang ingin mengikuti pengajian yang apabila tidak diijinkan maka lansia akan merasa bosan dan suntuk tinggal di rumah dan merasa tidak berharga. Dukungan ini dapat bermanfaat bagi lansia untuk memenuhi kebutuhan psikologis dan sosialnya.

Dengan diberikannya dukungan instrumental, dukungan informasional, dukungan emosional, dan dukungan penghargaan tersebut oleh keluarga kepada lansia, dan dapat terpenuhi kebutuhan fisik dan psikologis sosial lansia maka berarti keluarga sudah memberikan dukungan sosial dengan baik kepada lansia. Dukungan sosial dari keluarga sangat penting bagi lansia terutama lansia yang sudah tidak potensial karena apabila tidak ada dukungan sosial dari keluarga maka lansia tersebut akan menjadi terlantar dan akan menimbulkan permasalahan baru baik bagi individu lansia sendiri, bagi keluarga maupun bagi masyarakat dan pemerintah.

\section{IMPLIKASI}

Hasil penelitian tentang dukungan sosial keluarga terhadap lanjut usia diharapkan dapat memberikan implikasi baik secara teoritis maupun secara praktis. Secara teoritis, hasil penelitian ini diharapkan dapat memberikan masukan untuk pengembangan ilmu dan konsep di bidang pekerjaan sosial dan kesejahteraan sosial, khususnya konsep-konsep yang berhubungan dengan dukungan sosial.

Secara praktis, hasil penelitian ini diharapkan dapat memberikan masukan untuk pengembangan praktik dan kajian pekerjaan sosial khususnya praktik dan kajian yang berhubungan dengan kelanjutusiaan.

\section{DAFTAR PUSTAKA}

Camelia Kristika Pepe, dkk. Dukungan Sosial Keluarga dalam Memenuhi Kebutuhan Lansia di Panti. 118SHARE: Sosial Work Jurnal, VOLUME: 7 No: 1-29. ISSN: 23390042 (p). ISSN: 2528-1577 (e). Diunduh Tanggal 7-5-2020.

Dwi Arini, dkk. Pengaruh Dukungan Sosial Keluarga terhadap Kualitas Hidup Lansia di Panti Werdha Ria Pembangunan Jakarta Timur. Jurnal Kesejahteraan Keluarga dan Pendidikan (JKKP). Vol. 03 No. 02 doi. Org/10-21009/JKKP.032.04. Diunduh Tanggal 7-4-2020.

Lilik Ma'rifatul Azizah. 2011. Keperawatan Lanjut Usia. Cetakan Pertama. Yogyakarta: Graha Ilmu

Program Nyaah Ka Kolot. https://jabarprov.go.id/index.php/news/289 61/2018/07/19/Numan-Kudu-Nyaah-KaKolot.

Rivanlee Anandar, dkk. Dukungan Sosial terhadap Anak Jalanan di Rumah Singgah. SHARE SOSIAL WORK JURNAL, VOLUME:5 Nomor:1, ISSN: 2339-0042. Diunduh Tanggal 12-4-2020

Sugiyono. 2016. Metode Penelitian Kuantitatif, Kualitatif dan R\&D. Bandung: PT Alfabet.

Sarafino. 2006, Muchlisin, 2017. Pengertian, Bentuk dan Manfaat Dukungan Sosial. https://www.kajianpustaka.com. Diunduh Tanggal 15-5-2020

Undang-Undang No. 13 Tahun 1998 tentang Kesejahteraan Lanjut Usia. www.bphn.go.id. Diunduh Tanggal 9-52020 